Rodzina, ekonomia i migracja. Ujęcie prawne i socjologiczno-ekonomiczne, red. Magdalena Butrymowicz, Piotr Kroczek, Kraków 2021, s. 7-28 (Biblioteczka Prawa, 4).

Bartłomiej Gapiński

https://orcid.org/oooo-0002-7285-0480

\title{
Ciocia i dziadek w rodzinie tradycyjnej. Niezamężne i ludzie starzy na tle społeczności chłopskiej
}

Przedmiotem tego tekstu jest ukazanie, jaki status społeczny mieli ludzie samotni (a konkretnie niezamężne, w mniejszej skali też bezżenni, którzy nie założyli rodziny i nie mieli dzieci) oraz starzy w perspektywie życia rodzinnego. Odnoszę się do społeczności wiejskiej, do „chłopskiej kultury tradycyjnej”, jak ją nazywał Kazimierz Dobrowolski ${ }^{1}$. Rozpatrywane będą losy dwóch członków rodziny: cioci i dziadka, gdyż są oni emblematycznym streszczeniem szerszych kategorii społeczno-kulturowych zarówno osób niezamężnych, bezżennych, jak i starych. W swoich rozważaniach nawiązuję głównie do schyłku II Rzeczypospolitej i czasów komunizmu, choć wplatam

1 Zob. K. Dobrowolski, Chłopska kultura tradycyjna (Próba teoretycznego zarysu na podstawie materiałów źródłowych XIX $i$ XX w. z południowej Małopolski), „Etnografia Polska” 1 (1958), s. 19-52. 
też relacje starsze, np. ze schyłku XIX wieku. W tekście odwołuję się do trzech zasadniczych źródeł: opublikowanej relacji etnograficznej z małopolskiego Zaborowa sprzed II wojny światowej (wydanej po wojnie) autorstwa Kazimiery Zawistowicz-Adamskiej (1897-1984), zbioru wywiadów zebranych przeze mnie w minionym pięcioleciu, a dotyczących kujawskiej animatorki kultury ludowej - Marii Patyk (1924-2011), wreszcie obszernego listu - w którym biskup łowicki senior Józef Zawitkowski (1938-2020)² opisał mi, jak w okresie stalinizmu wyglądało życie codzienne w mazowieckiej wsi Żdżary (sam pochodził z położonej dwa kilometry dalej niewielkiej wsi Wał, ale szerzej identyfikował siebie z wsią parafialną, czyli Żdżarami).

\section{Ciocia}

Samotność w kulturze tradycyjnej była postrzegana jako stan niepożądany, wszyscy zdrowi na ciele i umyśle winni realizować się w rolach żon i mężów, potem zaś matek i ojców. Wyjątkiem oczywiście byli ludzie, którzy wybierali kapłaństwo i życie konsekrowane. Generalnie jednak w świecie tym ontogeneza podporządkowana była filogenezie. Życie upodobnione było do relacji obserwowanych w przyrodzie, rodzina winna rodzić, obradzać, być płodna. Samotni owe prawa podważali. Wierzono w upersonifikowany Kosmos, który na wzór przyrody obdarowywał życiem, był płodny. Podkreśla Wojciech Józef Burszta:

Charakterystyczne [w światopoglądzie chłopskim] było [...] przekonanie o braku jakościowej różnicy między naturą a ludźmi, którzy stanowili jej część integralną - podobnie jak rośliny, zwierzęta,

2 Szerzej jego biografię prezentują: A. Żak, J. Skrzypnik, Życie w rytm Bożych nut. Opowieść o biskupie Józefie Zawitkowskim, Kraków 2021. 
zjawiska atmosferyczne etc. Można zatem wnioskować, że na tej płaszczyźnie nadrzędną wartością dla ludu wiejskiego było podtrzymywanie solidarności życia w przyrodzie³

Bezżenni i niezamężne podważali ów imperatyw niesienia życia, nie tylko się nie solidaryzowali z przyrodą, ale mogli ją obrazić, co skutkowałoby karą dotykającą także innych, postronnych. Byli jałowi, a w ówczesnej mentalności jałowość była „zarażalna”, mogła skazić, zanieczyścić.

Czyli samotni byli niestosowni, podważali pożądane relacje społeczne. Człowiek bez rodziny niewiele znaczył. Pochodną tego była szeroko zakrojona stygmatyzacja niezamężnych i bezżennych. Wnikliwym obserwatorem społeczności wiejskiej w Galicji u schyłku xıx wieku jest Wincenty Witos. Kreśli on w interesujący sposób życie starych panien i starych kawalerów, zdecydowanie jednak akcentując, że los kobiet był gorszy. W swoich wspomnieniach pozostawił takie oto świadectwo:

Staropanieństwo było uważane za wielkie upośledzenie, a do starych panien odnoszono się z niechęcią, nazywając je pogardliwie „ciotami”. Stare panny zostawały z tych, których nikt nie chciał, bo nie miały ani majątku ani urody, z panien, które przebierały zanadto aż zestarzały się i osiadły na koszu, $\mathrm{z}$ tych, co czując powołanie inne, nie chciały wyjść za mąż. Szły one też do klasztoru, jeżeli i ojcowie zdobyli się na potrzebną gotówkę albo też spędzały czas na modlitwie i rozmyślaniach, chodząc ponadto codziennie do kościoła. Niektóre cieszyły się dużym poważaniem szczególnie u gospodyń, które im też pomagały czym mogły. Z czasem „dewotki” straciły

3 W. J. Burszta, Kotwice pewności. Wojny kulturowe z popnacjonalizmem $w$ tle, Warszawa 2013, s. 217. 
wiele na powadze i stały się przedmiotem drwin ze strony wielkiej części ludności, która twierdziła złośliwie, że wtenczas ofiarowały serce Panu Jezusowi, jak go nikt nie chciał ${ }^{4}$.

W realiach patriarchalnej wsi polskiej przełomu XIX i xx wieku ewidentnie bardziej pozytywny stosunek miano do starych kawalerów. Posiadali oni pewien autorytet, który jednak tracili, kiedy obserwowano ich życie samotnicze, a szczególnie paranie się pracami kobiecymi z konieczności ${ }^{5}$.

Dzisiaj określenie „ciota” w przypadku osoby samotnej przeszło do historii, raczej nie funkcjonuje, a jeśli już się pojawia, to w innym znaczeniu. Zastąpił je zwrot: „ciocia”. Prowadząca współcześnie badania etnograficzne w powiecie limanowskim Inga Kuźma na ogół spotykała się już z tłumaczeniem w rodzaju: „No to «ciocia», tak się je nazywa, te, co sobie męża nie brały"6.

Jeszcze jednakże w czasach bliskich współczesności rejestrowano zadawnione archaizmy kulturowe. Rejestrująca w latach 50. xx wieku etnograficzne badania terenowe w Załęczu Wielkim w Łódzkiem Wanda Drozdowska pokazuje, że samotni byli grupą stygmatyzowaną. Etnografka podała, iż za starą pannę uznawano już dziewczynę w wieku 25-27 lat, zaś po 30 roku życia wprost mówiono o takiej „ciota”. Starym kawalerem był mężczyzna około 30 roku, po 35 roku

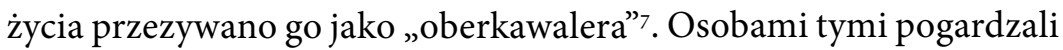

4 W. Witos, Dzieła wybrane, t. 1: Moje wspomnienia, cz. 1, przedm. E. Karczewski, J. R. Szaflik, Warszawa 1998, s. 85-86.

5 Por. W. Witos, Dzieła wybrane, t. 1: Moje wspomnienia, cz. 1, dz. cyt., s. 86.

6 I. Kuźma, Współczesna religijność kobiet. Antropologia doświadczenia, Wrocław 2008, s. 162.

7 W. Drozdowska, Grupy rówieśnicze w Załęczu Wielkim (podział, obrzędy recepcyjne, życie towarzyskie), „Prace i Materiały Muzeum Archeologicznego i Etnograficznego w Łodzi. Seria Etnograficzna” 5 (1961), s. 103. 
sąsiedzi, nie szanowała ich także wspólnota wiejska, np. zwracając się bezosobowo lub mówiąc na „ty”, wprost po imieniu, podczas gdy do pełnoprawnych gospodarzy zwracano się przez „wy”.

Tu jest kwestia kluczowa: osoby samotne stosunkowo rzadko były samodzielnymi gospodarzami. Obyczaj wiejski nakazywał przekazanie odziedziczonego gospodarstwa po rodzicach komuś z bliższych krewnych, którzy założyli rodzinę: bratu, siostrze, bratanicy, bratankowi, siostrzenicy, siostrzeńcowi w pierwszej kolejności. Tym samym bezżenni i niezamężne mieli status niepełnych dorosłych, traktowano ich infantylnie, a wręcz ekonomicznie wykorzystywano, uważając za tanią siłę roboczą ${ }^{8}$.

Nie oznacza to, że tacy ludzie nie posiadali życia wewnętrznego. Tak o osobie określanej jako ciotka, inaczej ujna, opuszczonej przez męża alkoholika i pozostawionej samej sobie pisała Zawistowicz-Adamska: „Należy do tych ludzi, którzy skazani na samotność, wzbogacają swój świat wewnętrzny ciągłym rozmyślaniem, mając zawsze oczy szeroko rozwarte na cały otaczający świat. Najmniej zajmuje

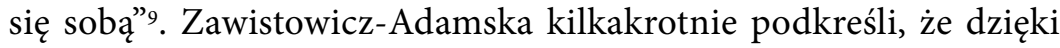
„ciotce” rozeznała społeczność wiejską Zaborowa, osoba ta okazała się niezwykle pomocna, znająca charaktery, towarzysząca i wspomagająca etnografkę w sytuacjach codziennych, zwłaszcza kiedy badaczka znosiła własne kryzysy i załamania w związku z trudami obserwacji terenowych.

Społeczność wiejska to, jak podają socjologowie, przede wszystkim wspólnota rodzin. Wszystko podporządkowane było rozwojowi rodowemu, nie indywidualnemu. Ludzie określali się jako „my”, bardzo rzadko jako „ja”, a zwracanie się przez „ty” (bezpośrednio po imieniu)

8 Por. W. Drozdowska, Grupy rówieśnicze w Załęczu Wielkim..., dz. cyt., s. 104.

9 K. Zawistowicz-Adamska, Społeczność wiejska. Wspomnienia i materiały z badań terenowych. Zaborów 1837-38, Warszawa 1958, s. 118. 
stanowiło piętno i było upokarzające - prowadziło często do zwady. Życie zbiorowe w pełni dominowało nad indywidualnym.

$\mathrm{Na}$ tym tle ciekawa jest sylwetka animatorki kultury ludowej z Kujaw Marii Patyk. Będąc starą panną, poświęciła się społeczności Sławska Wielkiego, gdzie uczyła przez lata jako nauczyciel biologii. Była typowym altruistą, porównywano ją do Siłaczki. Cechowało ją oddanie dla społeczności lokalnej i dla rodziny. Mówiono o niej jako o cioci. W rodzinie niewątpliwie Maria Patyk miała oparcie, najbliżsi doceniali jej oddanie dla innych i wspierali w szeregu praktyk. Ksiądz Otton Szymków ze Strzelna zapamiętał:

To była osoba bardzo otwarta na problemy ludzi i na biedę ludzi, i okazuje się, że rodzina za jej trud jej pracy, to zaangażowanie bardzo była wdzięczna. Widać było, że ciocia przyjechała, to ciocia przyjechała, do tej cioci wszyscy lgnęli. Ona miała coś takiego, taki magnes, że ona przyciągała do siebie ludzi, przyciągała wszystkich ${ }^{10}$.

Rys pracy dla innych silnie przebija się w relacjach wspominających ją osób. Tak kontynuuje swoją wypowiedź ks. Szymków, z którym animatorka przez lata współpracowała:

Ona nie wyszła za mąż, może właśnie dlatego, żeby poświęcić się drugiemu człowiekowi od tego najmniejszego do najstarszego i pracując dla dobra właśnie społeczności, bo tak nie miałaby tyle czasu wolnego. Jakby miała dzieci, to musiałaby pracować w domu i tak dalej, obowiązki by były już inne. A tak nie wyszła za mąż i okazuje się,

10 B. Gapiński, Maria Patyk. Kobieta niezwykła. Kujawska animatorka kultury i społecznik, Gniezno 2018, s. 21. 
że ten czas wolny cały poświęciła, po prostu byśmy powiedzieli w całości oddała się społeczeństwu ${ }^{11}$.

To samo podkreśla Barbara Tomaszewska - hafciarka i członkini zespołu „Kujawy” (solistka) założonego przez animatorkę w 1965 roku: „Bardzo dużo się poświęcała, sama samotna była, to mogła się poświęcić. Jakby była mężatką, to rodzina już by dużo czasu zajęła..., ale tak bardzo, od rana do wieczora służyła ludziom" ${ }^{12}$.

Prócz oddania dla szkoły, zespołu muzycznego czy koła gospodyń w Sławsku Wielkim pamiętała nieustannie o rodzinie z Pieck na Kujawach, wiedziała, że należy jej pomóc zwłaszcza podczas żniw czy wykopków. Nie wyobrażała sobie, by nie przyjechać do rodzinnego domu w trakcie wakacji i nie pomagać podczas sprzętu zboża, to zresztą powodowało, że wakacje nie były dla niej czasem relaksu, jak dla innych nauczycieli, lecz czasem pracy w rodzinnym gospodarstwie. Opowiada jej siostra Jadwiga Kowalska:

Trzydzieści lat była w Sławsku, ale ona nigdy w życiu na wczasach żadnych nie była, nigdy w życiu, tylko do nas na żniwa przyjeżdżała. Tak przyjeżdżała i pomagała, i sprzątała, i wszystko, i z nami szła wiązać, stogi stawiała, była na stogu zawsze, stawialiśmy przecież stogi dawniej ${ }^{13}$.

Nie był to przypadek odosobniony, gdyż czy to dzieci, czy dorośli ze Sławska Wielkiego, gdzie uczyła, pomagali rodzinie Marii w Pieckach, i to nie z przymusu, lecz raczej z życzliwości. Za wszystkimi tymi działaniami - od darcia pierza, przez pomoc w gospodarstwie,

11 B. Gapiński, Maria Patyk..., dz. cyt., s. 61.

12 B. Gapiński, Maria Patyk..., dz. cyt., s. 61.

13 B. Gapiński, Maria Patyk..., dz. cyt., s. 20. 
po opiekę nad dziećmi - stała owa kobieta, która choć samotna starała się pomagać najbliższym - siostrze i czterem braciom, którzy założyli własne rodziny.

Przewyższała otoczenie swoim wykształceniem (studiowała biologię w Łodzi), pedagogicznym doświadczeniem, aktywnością jako animator kultury (założyła zespół ludowy i przewodziła lokalnemu kołu gospodyń wiejskich), wreszcie wybijała się dzięki wprawie w haftowaniu i propagowaniu haftu kujawskiego (zorganizowała blisko 60 kursów hafciarskich na Kujawach, przyczyniając się do renesansu tego rękodzieła). Szczególnie aktywizowała przy tym osoby wykluczone, żyjące w samotności bądź mające już problemy starcze ${ }^{14}$. Pozostała jednak skromną ciocią, dla której najważniejsi byli najbliżsi. Jest ciekawym przykładem na to, jak odnieść sukces - wszak była najbardziej rozpoznawalnym twórcą ludowym na Kujawach Zachodnich, i z drugiej strony zdać się na rodzinę, pracować dla niej. Widać w niej dwie postawy -1) osoby aktywnej w okresie Polski Ludowej i zarazem 2) typowe dla społeczności wiejskiej umniejszanie siebie i poświęcenie osoby samotnej przede wszystkim dla rodziny, a także dla społeczności Sławska Wielkiego. Nie była to osoba mówiąca o sobie per „ja”, ale szukająca zakorzenienia i oparcia w „my”, w podmiocie zbiorowym.

Określenie „ciocia”, „ciotka” jest charakterystyczne dla niezamężnych kobiet na wsi. Jak podaje Inga Kuźma, ciotki są w relacjach rodzinnych najbliższą rodziną - pod względem pokrewieństwa to siostry matki bądź ojca. Stąd na kobiety samotne patrzono jak na osoby bliskie czy spoufalone ${ }^{15}$. Jak już wspomniałem, przytaczając Witosa, o osobach takich dość długo mówiono „ciota”, czyli łączono kobiety

14 Por. K. Dziubata, Kto pamięta o dziedzictwie? Działania na rzecz niematerialnego dziedzictwa kulturowego w Sławsku Wielkim i Przyprostyni, w: Kultura i krajobrazy pamięci, red. M. Dziewierski, B. Pactwa, Katowice 2020, s. 302.

15 Por. I. Kuźma, Współczesna religijność..., dz. cyt., s. 163. 
stanu wolnego ze złem, uważano, że były sługami szatana, że mogły zaszkodzić, parały się czarami i posiadały wiedzę czarnoksięską. To negatywne piętno zanikło wraz z kulturą ludową. Współcześnie pozostaje w użyciu quasi-rodzinne określenie „ciocia”, ktoś bliski siostra rodzica. Tym samym z określenia obelżywego, wykpiwanego, budzącego trwogę i pogardę stało się ono określeniem pozytywnym, ciepłym, poufałym, świadczącym o zmianie wizerunku. Zresztą nawet społeczność tradycyjna opiekowała się ciociami, wujkami, stryjkami, babciami, dziadkami, którzy też mieli wiele do powiedzenia w zakresie kontroli społecznej ${ }^{16}$. W tej materii dużo się zmieniło w związku z zanikiem wielkiej rodziny i zdominowaniem przestrzeni społecznej przez model rodziny nuklearnej, niemniej przykład „cioci” pokazuje, że mamy tutaj do czynienia z kontynuacją. Również wspomniany przeze mnie brak niezależności ekonomicznej samotnych odszedł wraz z przemianami powojennymi do przeszłości. Stało się tak także dlatego, że zmieniły się relacje rodzinne, rodzina $\mathrm{z}$ dziećmi przestała być wyłącznym akceptowalnym wzorem kulturowym, zaistniała większa wariantywność ról społecznych, w tym tych pozarodzinnych. Współcześnie wręcz pojawili się niezależni ekonomicznie ludzie stanu wolnego, na dobre ugruntowani w kulturze tak zwanych „singli”.

\section{Dziadek}

Odmienna była sytuacja osób starych, które to miały w społeczności wiejskiej znaczny autorytet. Przy nich koncentrowała się pamięć, oni strzegli tradycji, wreszcie podczas odpustów czy urodzin spotykała się przy nich rodzina. W kulturze ludowej wszystko musiało

16 Por. K. Zamorski, Pojęcie tradycyjnej społeczności wiejskiej w polskiej literaturze socjologicznej i etnograficznej, „Roczniki Dziejów Społecznych i Gospodarczych” 46 (1985), s. 133 . 
mieć ugruntowanie w przeszłości, a właściwie w wiejskim czasie „zawsze” (jak to formułował Stefan Czarnowski ${ }^{17}$ ), stąd potrzebni byli depozytariusze tradycji - ludzie starzy, posiadający autorytet osobowy. Starcy mieli za sobą doświadczenie życiowe, zdobyli wiedzę i wprawieni byli w relacje face to face, nabyli szereg doświadczeń w toku praktyk rolniczych, rzemieślniczych i społecznych. Stanowili w wiejskim izolowanym świecie najważniejsze źródło wiedzy ${ }^{18}$. Struktura owej wiedzy miała w dużym stopniu charakter sekretny, tajemny, przekazywany nie każdemu, lecz nielicznym, co potęgowało autorytet ludzi starych (zabiegano o to, aby się zdobytą mądrością podzielili) ${ }^{19}$.

W sferze publicznej i domowej obowiązywał takt i szacunek wobec seniora. Starano się używać określeń synonimicznych względem słowa „stary”, sięgano do zdrobnień wskazujących na spoufalenie, na przykład o dziadku wyrażano się „dziadziuś. Tak wspomina swoje rodzinne relacje pochodzący $\mathrm{z}$ mazowieckiej wsi bp Józef Zawitkowski:

Na dziadka nie mówiło się dziadek,

bo chodziło wtedy po wsi dużo żebraków,

na nich się mówiło dziady.

Rodzice też straszyli dzieci - dziadem.

Mówić do dziadka - dziadku

było niegrzecznie, grzecznie

mówiło się-dziadziuś ${ }^{20}$.

17 S. Czarnowski, Podłoże ruchu chłopskiego, w: S. Czarnowski, Dzieła, t. 2, Warszawa 1956, s. 168.

18 Por. K. Dobrowolski, Chłopska kultura..., dz. cyt., s. 32.

19 Por. K. Dobrowolski, Chłopska kultura..., dz. cyt., s. 32-33.

20 List bp. Józefa Zawitkowskiego do autora. Wspomnienia z dzieciństwa [2011]. 
Na co dzień do seniorów zwracano się w drugiej osobie liczby mnogiej („babciu, podajcie chleb”), a w czasie nieobecności seniora w trzeciej osobie liczby mnogiej („dziadek poszli do kościoła”); było to tak zwane dwojenie i trojenie, wskazujące na szacunek, respekt, poważanie wobec nestorów rodzinnych.

Ludzie starzy nie byli w stanie sprostać wyzwaniom wiejskiej ekonomii, na ogół nie wykonywali już ciężkich prac polowych, bali się zaliczenia do grona niepotrzebnych, bezużytecznych, chorych. Wieś tradycyjna nie miała zrozumienia dla choroby i inwalidztwa ${ }^{21}$, w skrajnych sytuacjach uznawała wręcz, że kalecy są nie do końca ludźmi, lecz istotami demonomorficznymi, groźnymi hybrydami pozostającymi $\mathrm{w}$ relacji ze sferą $\mathrm{zła}^{22}$. Istniała jednak sfera, która pozwalała schorowanym i słabym seniorom obronić się przed zupełnym zdegradowaniem. Była to ówczesna kultura religijna. Stefan Czarnowski wspomina, że seniorzy mieli w społeczności wiejskiej ugruntowaną pozycję autorytetów; był to autorytet formalny osób, które poprzez modlitwę bronią się przed bezużytecznością ${ }^{23}$. Można powiedzieć inaczej, że poprzez pracę modlitewną rekompensowali sobie pracę fizyczną. Inne grupy to doceniały. Kazimiera Zawistowicz-Adamska pisze o Dziadku z małopolskiego Zaborowa, którego życie codzienne wyglądało podobnie, przy czym kluczowe dlań były poranne praktyki religijne:

Zjada na śniadanie żur z ziemniakami, trochę się krząta po obejściu i wyrusza do kościoła na mszę. Wspierając na kiju przygarbioną

21 Por. E. Szpak, Mentalność ludności wiejskiej w PRL. Studium zmian, Warszawa 2013, s. 210.

22 Por. O. Zadurska, Ludowy wizerunek dzieci kalekich i jego społeczne konsekwencje, „Litteraria Copernicana” 2017 nr 3 (23), s. 61, https://apcz.umk.pl/czasopisma/ index.php/LC/article/view/LC.2017.050 (9.11.2019).

23 Zob. S. Czarnowski, Kultura religijna wiejskiego ludu polskiego, w: S. Czarnowski, Dzieła, t. 1, Warszawa 1956, s. 105-106. 
postać, idzie raźno, równym, mocnym krokiem, odziany w ciężki kożuch, który nosi od wczesnej jesieni do późnej wiosny, jako że na starość krew już nie grzeje tak jak za młodu. W kościele siada zawsze na tym samym miejscu: bliżej ołtarza, po prawej stronie koło chorągwi. Rozmyśla o dusznym zbawieniu, $\mathrm{z}$ dnia na dzień sposobiąc się do wędrówki w zaświaty ${ }^{24}$.

W cytacie tym pojawiają się kolejne $\mathrm{z}$ istotnych cech ówczesnego wymiaru starości - transgraniczność i transgresja. Byli bowiem seniorzy bliscy śmierci, zaświatom, ich słabnące atrybuty przejawiające się poprzez niedowidzenie, niedosłyszenie, dolegliwości układu kostnego $\mathrm{i}$ inne starcze dysfunkcje uznawano za zwiastuny bycia w innej kondycji - już typowej dla zaświatów ${ }^{25}$. Stąd Dziadek z Zaborowa modli się i przygotowuje do wędrówki w zaświaty dzień w dzień w kościele - inni ze społeczności wiejskiej bacznie to obserwują. To respekt dla człowieka będącego niemal już w innej rzeczywistości, człowieka, którego drugim domem jest kościół i porządek sakralny (wówczas rozumiany w kontekście synkretyzmu religijno-magicznego, dodajmy: dziadek też zna się na magii, informuje, że potrafi zauroczyć).

Religia była najważniejszą przestrzenią aktywności osób starych, w tym wymiarze głównie się realizowały. Historyk Włodzimierz Mędrzecki w swojej książce o młodzieży wiejskiej w Polsce centralnej przywołał świadectwo jednego z włościan z okresu międzywojennego, tak wspominającego swego dziadka:

Do najpiękniejszych momentów lat dziecinnych zaliczam Wigilię Bożego Narodzenia [...] pamiętam zawsze po spożyciu pośnika

24 K. Zawistowicz-Adamska, Społeczność wiejska..., dz. cyt., s. 93.

25 Por. B. Walęciuk-Dejneka, Ludowy obraz kobiety - perspektywa inności. Folklor i literatura, Siedlce 2014, s. 24. 
dziadek siadał na krawędzi łóżka, odświętnie jak przystało ubrany w nową koszulę lnianą, zawiązany pod szyją czerwoną tasiemką. [...] Od czasu do czasu zażywając tabakę opowiadał długo, długo w noc ze znajomością najmniejszych szczegółów o Narodzeniu Chrystusa, o Pastuszkach, o Trzech Królach i Herodzie okrutniku. [...] W końcu dziadek przechodził do legend i opowiadał o strachach i duchach pokutujących na wsi ${ }^{26}$.

Podobnie wypowiada się o już wspomnianym 9o-letnim Dziadku z Zaborowa Zawistowicz-Adamska:

Siedzimy z Dziadkiem na ławie koło pieca. Jest Boże Narodzenie. W kącie izby jarzy się choinka. Dziadek wygląda odświętnie. Wprawdzie ma na sobie zawsze ten sam kożuch, ale wygolony jest starannie (goli się na każdą niedzielę), wąsy ma krótko przystrzyżone, siwe włosy ułożone są koło uszu w pukle, bo Dziadek nosi długie włosy wedle starej mody. Piękny orli profil rysuje się wyraziście na tle wybielonego pieca. Dziadek ma w rękach wielką książkę do nabożeństwa, z której modli się z górą pół wieku ${ }^{27}$.

Powyższe cytaty ukazują człowieka starego jako przedstawiciela przede wszystkim kultury rodzinnej, to on przekazuje rodzinie pamięć po tych, którzy odeszli, to on w wieczór wigilijny opowiada o historiach biblijnych (zgodnych z „biblią ludową”), on modli się i przewodzi tego wieczora modłom. To nie przypadek - w momencie fuzji tego świata $\mathrm{z}$ zaświatami podczas wieczoru wigilijnego potrzebne jest przywołanie osoby bliskiej tamtej rzeczywistości jako mediatora, w tej

26 W. Mędrzecki, Młodzież wiejska na ziemiach Polski centralnej 1864-1939. Procesy socjalizacji, Warszawa 2002, s. 147.

27 K. Zawistowicz-Adamska, Społeczność wiejska..., dz. cyt., s. 98. 
mitycznej i magiczno-religijnej czasoprzestrzeni potrzeba odnieść się do pośrednika, a takim był człowiek stary. Od seniora rozpoczynał się wieczór wigilijny, konkretnie od jego modlitwy, zaintonowanej kolędy, to gospodarz po złożeniu życzeń swej małżonce łamał się opłatkiem według zasady starszeństwa, od starych rodziców poczynając.

Rodzina była podstawową przestrzenią aktywności ludzkiej. Pełniła szereg funkcji: produkcyjną, prokreacyjną, wychowawczą, integracyjno-ekspresyjną, religijną, kulturową, rekreacyjną, zabezpieczającą $^{28}$. Człowiek stary miał zapewnione dożywocie. Świadczenia dożywotnie różnie nazywano w zależności od regionu, najpopularniejsze to wycug i wymowa. Po prostu dzieci przejmujące gospodarstwo albo gwarantowały rodzicom - „wycuźnikom” - utrzymanie za zrzeczenie się włości, albo pozostawiały im część roli i zagrody, by mogli przy niewielkiej pomocy z zewnątrz się utrzymać. W zaborze pruskim i częściowo rosyjskim te świadczenia były spisywane, na pozostałych terenach, a zwłaszcza w Galicji, zadowalano się umową ustną. Na ogół umowy dożywotnie były wygórowane i często podczas na przykład Wielkiego Kryzysu czy II wojny światowej pozostawały tylko postulatem, a w obliczu panującej nędzy seniorzy dopominali się o niewielką ich część. Czasami zrzekanie się majątku było formą degradacji, prowadzącą wręcz do żebractwa, bywało, że dzieci okazywały się wyrodne, mogło nawet dochodzić, o czym informowała prasa przełomu xıx i xx wieku, do fizycznego znęcania się i rękoczynów ${ }^{29}$. Władysław Orkan zapamiętał podhalańską

28 Por. U. Lehr, U schyłku życia. Starość mieszkańców wsi Beskidu Śląskiego i Podhala, Warszawa 2007, s. 127.

29 Por. W. Mędrzecki, Uwagi o starości na wsi polskiej w XIX wieku, w: Ludzie starzy i starość na ziemiach polskich od XVIII do XXI wieku (na tle porównawczym), t. 1: Metodologia, demografia, instytucje opieki, red. A. Janiak-Jasińska, K. Sierakowska, A. Szwarc, Warszawa 2016, s. 8o-81. 
wersję Czwartego przykazania: „Czcij ojca, matkę i obchodź się z nimi dobrze... dopokąd ci gruntu nie zapiszą" ${ }^{\circ}$.

Ludzie starzy często też wychowywali najmłodsze pokolenie. Pierwszorzędnie uczyli dzieci posłuszeństwa względem rodziców i oddania dla rodziny. Przekazywali informacje o wiejskich obowiązkach, pracy w domu i na gospodarstwie. Dziadkowie na ogół wychowywali wnuków, babcie niańczyły wnuczki. Seniorzy bawili się i przechadzali $\mathrm{z}$ dziećmi. Uczuć intymnych w przestrzeni publicznej na ogół nie okazywali, ale czynili to w zaciszu domowym. Babcie ponadto bardzo często wyróżniały się jako osoby kojarzące małżeństwa. Seniorzy generalnie stali na straży moralności wiejskiej.

Ludzie sędziwi najbardziej obawiali się zakwalifikowania do grupy osób bezużytecznych. Póki starczało sił, starali się pomagać rodzinie, zmywali naczynia, gotowali, niańczyli wnuków, pilnowali kóz czy drobiu, chodzili do lasu zbierać chrust, a latem maliny. Starano się za wszelką cenę oddalić widmo bezużyteczności. Osłabienie organizmu jednak postępowało, nie dało się wszystkiego wykonywać samemu, należało się zdać na innych, wreszcie u kresu życia leżało się bezwładnie na piecu czy w łóżku i doczekiwało końca. „Nicnierobienie" było w tym wiejskim świecie największym piętnem, u człowieka złożonego ciężką chorobą wywoływało wręcz wolę odejścia $\mathrm{z}$ tego świata ${ }^{31}$. Stąd póki starczyło sił, starano się choć symbolicznie pomagać tym, którzy prowadzili gospodarstwo.

30 T. Kalniuk, Mityczni obcy. Dzieci i starcy w polskiej kulturze ludowej przełomu XIX $i$ XX wieku, Toruń 2014, s. 121-122.

31 Por. U. Lehr, Od dożywocia do emerytury. Społeczno-kulturowe uwarunkowania strategii przetrwania, w: Ludzie starzy i starość na ziemiach polskich od XVIII do XXI wieku (na tle porównawczym), t. 2: Aspekty społeczno-kulturowe, red. A. Janiak-Jasińska, K. Sierakowska, A. Szwarc, Warszawa 2016, s. 138. 
Przestrzenią osób starych był ogród, oni szczepili drzewa, zbierali owoce, starzy chłopi doglądali pasieki pszczół. Tak wspomina bp Zawitkowski:

Dziadziuś był pszczelarzem.

W ciężkie żniwne południe

najchętniej odpoczywał przy ulu,

gdzie wlatywały pszczoły.

Pszczoły go nie ugryzły.

Z wosku robił świece do kościoła ${ }^{32}$.

Nietypowa praca na gospodarstwie, jak pszczelarstwo czy sadownictwo, wyprawy po chrust do lasu, zbieranie na miedzach ziół i kwiatów (np. na Matki Boskiej Zielnej), dbanie o przydrożne krzyże i figury - wszystko to aktywności na terenach świata na wpółoswojonego czy nawet jak las nieoswojonego. Anekumena, w co wierzono, pozostawała $\mathrm{w}$ łączności $\mathrm{z}$ tamtym światem, dlatego ludzie starzy, kierujący się w te przestrzenie, byli na swój sposób zabezpieczeni przed działaniem sił demonicznych. Były to wręcz miejsca dla nich stworzone, im bliskie, przed którymi młodsze generacje drżały.

Seniorzy pomagali rodzinie także podczas prac polowych, o ile siły jeszcze na to pozwalały. Ziemia była podstawą chłopskiego sytemu aksjonormatywnego. Dawała poczucie spełnienia, dumy, honoru. Starcy nie lubili, jak ktoś z zewnątrz wtrącał się w ich wiejskie gospodarowanie. Biskup Zawitkowski zapamiętał traumatyczne wydarzenie z dzieciństwa, kiedy to jego dziadek zbuntował się podczas ściągania kontyngentów na rzecz państwa w okresie stalinizmu. Wspomina:

32 List bp. Józefa Zawitkowskiego..., dz. cyt. 
Najbardziej bolały chłopów

obowiązkowe dostawy zboża, mięsa

i to za marne grosze wg hektara.

Najtrudniej było bogatym.

Tych nazywano kułakami.

Takim kułakiem był mój dziadziuś.

Były ciężkie żniwa.

Woziliśmy snopki,

a na podwórku stał agent i krzyczał:

Dlaczego jeszcze nie odstawione

zboże dla państwa.

Dziadek nie wytrzymał,

chwycił za widły i po chłopsku

chyba by załatwił agenta,

ale ten uciekł.

Za to kolegium przysądziło

dziadkowi 3 dni aresztu - w żniwa ${ }^{33}$.

Tym, co wyróżniało ludzi starych, było spoufalenie ze śmiercią. Śmierć była oswojona (według określenia Philippe Arièsa ${ }^{34}$ ), czekano na nią. Liczono, że z jej nadejściem: wreszcie się odpocznie - po ciężkiej pracy na tym padole. Śmierć była przypominana przez innych. Oddajmy jeszcze raz głos Zawistowicz-Adamskiej:

[postronni chłopi zwykli idąc drogą pozdrawiać Dziadka w następujący sposób:]

33 List bp. Józefa Zawitkowskiego..., dz. cyt.

34 Ph. Ariès, Człowiek i śmierć, przeł. E. Bąkowska, Warszawa 1992, s. 19-41. 
Oj, Dziadku, Dziadku, a toście już starzy! Niedługo staniecie już na boskim sądzie!

[...] Ładne macie roki, Dziadku! Czas już na Was, choć jeszczeście krzepcy ${ }^{35}$.

Komentuje te zachowania etnografka:

Nawet najbliżsi mu tę rychłą śmierć przypominają. Z troskliwości. Bo tu się nie mówi o śmierci przyciszonym głosem. I nikomu nie dziwo, że dziadkowi życie dogasa powoli, że zmierza niepostrzeżenie ku mrokom wieczności, jak jesienny, cichy zmierzch ku cieniom nocy $^{36}$.

Jak można zauważyć, to typowa śmierć oswojona, na którą się przygotowywano, którą inni niejako przyzywają, mówią o niej bez ogródek i lęku, to przygotowanie do konania w otoczeniu rodziny, najbliższych i wspólnoty wiejskiej. O śmierci ot po prostu informowano, bez trwogi. Istotne w tym było, że ludzie sędziwi niwelowali opozycję życie - śmierć, żyjąc w przedziwnej rzeczywistości, jeszcze tu na ziemi i zarazem w przedsionku tamtego świata ${ }^{37}$. Stąd śmierć i pogrzeb seniora rodu stanowiły prawdziwe misterium, kiedy celebrowano wspólnotę wiejską. Samo teatrum pogrzebowe też reżyserował nierzadko konający, zwykłą koleją rzeczy było przyszykowanie sobie stosownego stroju do trumny. Wspomina bp Zawitkowski:

35 K. Zawistowicz-Adamska, Społeczność wiejska..., dz. cyt., s. 103.

36 K. Zawistowicz-Adamska, Społeczność wiejska..., dz. cyt., s. 103.

37 Por. B. Gapiński, Starość i religijność w społeczności chłopskiej, w: Doniosłość i powszedniość chleba, red. B. Gapiński, R. Stanek, Gniezno 2016, s. 104 (O Zdrowy Chleb, 4). 
Dziadziuś przygotował sobie na śmierć koszulę, kalesony, garnitur, buty.

Prosił tatę: „A do trumny włóż mi maciejówkę, bo czym się będę witał w niebie z Panem Jezusem i Matką Boską.

Daj mi w rękę różaniec i książeczkę, A w rękę przy zgonie daj mi gromnicę, tylko tę woskową. Jak zgaśnie włóż mi ją do trumny" 38 .

Rozważania biskupa pozwalają konstatować, że taka śmierć nie budziła strachu, była poprzedzona stosownym zachowaniem, mającym raczej naturę szykowania ubrania do dalekiej podróży; podobnie jak na tym świecie miało być na tamtym.

\section{Podsumowanie}

Bezżenni, niezamężne $z$ jednej strony i starzy z drugiej stanowili dwie grupy społeczne wyróżniające się w wiejskim świecie. Obie dotykała stygmatyzacja. Bezżenni i niezamężne musieli znosić poniżenie, podległość względem zamężnych przedstawicieli swojej wspólnoty rodzinnej, wysłuchiwać pod swoim adresem wiele żartów postronnych i zwracania się per „ty” nawet przez małe dzieci, co musiało boleć i było piętnem symbolicznym. Nie odgrywali ważniejszej roli w domu, na wsi czy w parafii. Jednak poprzez określenie „ciocia”, a rzadziej także „wujek” podkreślano w tradycji ludowej bliskość tych osób względem wielkiej rodziny, oni byli jej członkami. Oni się dla niej poświęcali. Nawet wyemancypowana, wyedukowana i rozpoznawalna na całych Kujawach Maria Patyk przede wszystkim działała z myślą

38 List bp. Józefa Zawitkowskiego..., dz. cyt. 
o rodzinie. Jeszcze w Peerelu funkcjonowało dawne obelżywe określenie „ciota”, ale ewidentnie rezygnowano z niego. Ciocia natomiast to ktoś bliski, kochany, na kim można się oprzeć, to osoba pomocna, życzliwa. Kiedy rodzina przestała być jedyną drogą życia, bezżenni czy niezamężne zyskali większą autonomię, stali się wręcz, co dawniej było nie do pomyślenia, niezależni ekonomicznie, mało tego - wyznaczali awans społeczny i odnosili sukcesy (na co też wpływ miała kultura masowa preferująca swoistą modę na singli).

Starzy ludzie jak ognia bali się zaliczenia do grona nieużytecznych, stąd, na co wskazałem, starali się angażować w sprawy domu, gospodarstwa, rodziny. Byli autorytetami, jeśli chodzi o przekaz tradycji. Wiejski ethos wręcz opierał się na ich zwornikowym autorytecie. W sytuacjach codziennych musieli jednak ustępować gospodarzom, mogli zostać nawet wygnani na żebry czy doświadczyć przemocy fizycznej, a w przestrzeni domowej byli często marginalizowani. Nawet gdy niedomagali, nie pozostawali bezużyteczni, gdyż niemożność wykonywania prac fizycznych rekompensowali „pracą” modlitewną. Młodzi zaniedbywali praktyki kultowe, starzy przeciwnie, póki mogli - chodzili do kościoła, na cmentarz, dbali o przydrożne figury, modlili się litaniami w domach i uczyli pacierzy dzieci. Było w tej mentalności echo wierzeń o zaświatach, najbardziej widoczne podczas obrzędów, takich jak wigilia, czy poprzez pogodzenie się z własną śmiercią.

Zarówno wyróżnioną tutaj „ciocię”, jak i „dziadka” cechowało oddanie rodzinie, w obliczu słabości - czy to społecznej, czy fizycznej - żyli oni z myślą o najbliższych. To niewątpliwie ludzie oddani swoim bliskim (w przypadku cioci także przyszywanym), poświęcający się dla innych, ludzie niekoncentrujący się na sobie, lecz rozumiejący, że żyją w wiejskim świecie „my”, we wspólnocie wiejskiej określanej jako „federacja rodzin”39.

39 I. Bukraba-Rylska, Socjologia wsi polskiej, Warszawa 2008, s. 141. 


\section{Streszczenie}

Tematem artykułu jest postrzeganie w chłopskiej kulturze tradycyjnej osób pełnoletnich, które funkcjonują w rodzinie, ale nie pełnią roli gospodarza czy gospodyni domu. Są to dwie kategorie: ludzie samotni (bezżenni) i starzy. Ci, którzy nie założyli własnej rodziny, żyjąc w stanie wolnym, i ci, którzy zdali gospodarstwo, stając się wycuźnikami. Symbolem jest tutaj niezamężna ciotka i stary dziadek. Bazuję na materiałach z Kujaw (działalność animatorki kultury Marii Patyk), opisie społeczności Żdżary na Mazowszu (wspomnienia bp. Józefa Zawitkowskiego) i relacji etnograficznej z małopolskiego Zaborowa Kazimiery Zawistowicz-Adamskiej. Materiał źródłowy odnosi głównie do realiów okresu od schyłku in Rzeczypospolitej do końca komunizmu. Przestrzenią, w jakiej ujęto samotność i starość, jest głównie życie codzienne. Rodzina w tej kulturze odgrywała doniosłą rolę - determinowała życie, stąd społeczność wiejska nie bez przyczyny określana jest jako „federacja rodzin”. W relacji do tej wspólnoty pozostawali samotni - otaczani przez wielką rodzinę opieką (troszczącą się o ciocię i wujka), czy też ludzie starzy, względem których dzieci-gospodarze miały zobowiązania. Jednak obie kategorie społeczne: samotni i starzy, w przestrzeni społecznej były też stygmatyzowane, co również staje się przedmiotem refleksji.

Słowa kluczowe: tradycyjna społeczność wiejska, niezamężne kobiety, „stare panny", ludzie starzy, dziadkowie

\section{Summary}

Aunts and grandfathers in traditional families.

The unmarried and the old in peasant societies

The subject of this presentation is the way the adults who function in families, but are not the owners of farms are perceived. There are two categories: single people (unmarried) and the old. The first group consists of the people who did not start their own families and the second are the ones who passed their farms to their families thus becoming so-called "wycuźnik." An unmarried aunt and an old grandfather both stand as the symbols of the mentioned categories. I base my work on materials from Kujawy (the activity of cultural animator - Maria Patyk), the description of the society of Żdżary in Mazowsze (Bishop Józef Zawitkowski's memories) and the ethnographic 
report from Zaborów in Małopolska by Kazimiera Zawistowicz-Adamska. The materials mainly refer to the end of Second Polish Republic till the end of communism in Poland. I will concentrate on families and old age mainly in reference to everyday life. In peasant culture, it was the family who determined whole lives. That is why, peasant societies are described as "federations of families." In such communities there existed the unmarried - taken care of by their big family (who looked after their aunts and uncles), and, the old - towards whom their offspring had certain obligations. However, both these social categories the lonely and the old were discriminated against in societies - the problem I also attempt to focus on.

Keywords: peasant rural community, unmarried women, old maids, old people, grandfathers 